


\title{
Geomorphological study of Quaternary tectonics of the Doon Valley, Garhwal Himalaya, Uttranchal, India
}

\author{
R. C. Patel and Yogesh Kumar \\ Department of Earth Sciences, Kurukshetra University, Kurukshetra-136119, India
}

\begin{abstract}
The post-major Himalayan tectonics is distinctly reflected on the present day topography of the Doon Vatley. The photogeological characters and field study show that the Doon Valley is bounded by major faults. NE-dipping Main Boundary Thrust (MBT) surrounds it in the north, Mohand Thrust and Bhimgoda Thrust in the south, the Ganga Tear Fault in the east and the Yamuna Tear Fault in the west. Due to ongoing continental convergence of the Indian and Eurasian plates, the valley is tectonically unstable today. Vertical as well as horizontal movements are ongoing processes of the valley. The terraces along river valleys, bending of the river courses, tilting of the piedmonts, shifting of the river courses, overriding of the Lesser Himalayan rocks over the Doon Valley and Siwalik rocks over Indo-Gangetic plain are the consequence of it. Several lineaments, majorly longitudinal and transverse, are tearing up the Doon Valley. Out of them, some have segmented the recent Doon gravels, which reflect the Quaternary tectonics of the Doon valley. The probable cause of the Quaternary tectonics of the Doon Valley might be due to the northward pushing of the Delhi-Haridwar ridge.
\end{abstract}

\section{INTRODUCTION}

The Himalaya is a living mountain building laboratory to understand the mechanism and consequence of continental collision. At the initial stage, the deformational front was confined along the Indus-Tsangpo Suture Zone (ITSZ) and then gradually shifted towards south. With the process of episodic evolution of the Himalaya, the deformational front was shifted along the Zanskar Shear Zone (ZSZ)/TransHimadri Thrust (THT) (Patel et al. 1993; Valdiya 1989), Main Central Thrust (MCT) and Main Boundary Thrust (MBT) (Molnar and Toppanier 1975; Norton and Sclater 1979; Powell 1979; Valdiya 1980; Patriat and Acache 1984). At present, the deformational front is at the foot of the Siwalik Hills in India and Nepal where the Main Frontal Thrust (MFT) (Nakata 1989) marks it and at the foot of salt Range of Pakistan where it is named as the Salt Range Thrust (Yeats et al. 1984). Post collision deformational processes in the Himalaya are reflected in the development of large-scale lineaments, tilting and shifting of river courses and piedmonts, and uplift of the river terraces. In India and in other parts of the Himalaya, the expression of the neotectonic activity is more subdued and as a result the siesmotectonic significance of this zone has been recognized only (Nakata 1972; Rastogi 1976; Chandra 1978; Khattri et al. 1971; Khattri and Tyagi 1983; $\mathrm{Ni}$ and Barazangi 1984)

The Doon Valley has experienced repeated pulses of Quaternary tectonics. The tectonics in the form of both vertical uplift and horizontal movement along tectonic lines has played an important role in carrying out its present geomorphic configuration. The main objectives of the present work are:
1) to decipher the ongoing Quaternary tectonics by various features such as lineaments and fault traces and geological and geomorphological landforms in the region on the basis of aerial photographs, satellite imageries and field studies and

2) design tectonic model for Quaternary evolution of the Doon Valley by integrating all the data.

\section{AERIAL PHOTOGRAPHS AND SATELLITE IMAGERIES SURVEY}

In the present study, aerial photographs used are of scale 1:40,000 and the satellite images used are LANDSAT MSS-5 and MSS-7 on 1:250,000. Based on the MSS-7, the network of river systems are marked and compared with data map prepared using aerial photographs. This is the base map on which subsequent data are plotted (Fig. 1). The geological map thus prepared is compared with satellite data and geological map prepared by different workers (Meijerink 1974; Raiverman et al. 1984) and it is found that they are similar. Geomorphological features are used in delineation of structural features. Faults are marked by displacement of lithic units, sudden change in the width of the river course, abnormal curvatures of the rivers, their shift and alignments, etc. All the rock units are identified by photocharacters such as tone, colour, texture, drainage pattern, etc.

\section{GEOLOGICAL FRAMEWORKS AND TECTONIC SETTING}

The Doon Valley is an intermountain longitudinal depression of tectonic origin. From the photogeological 


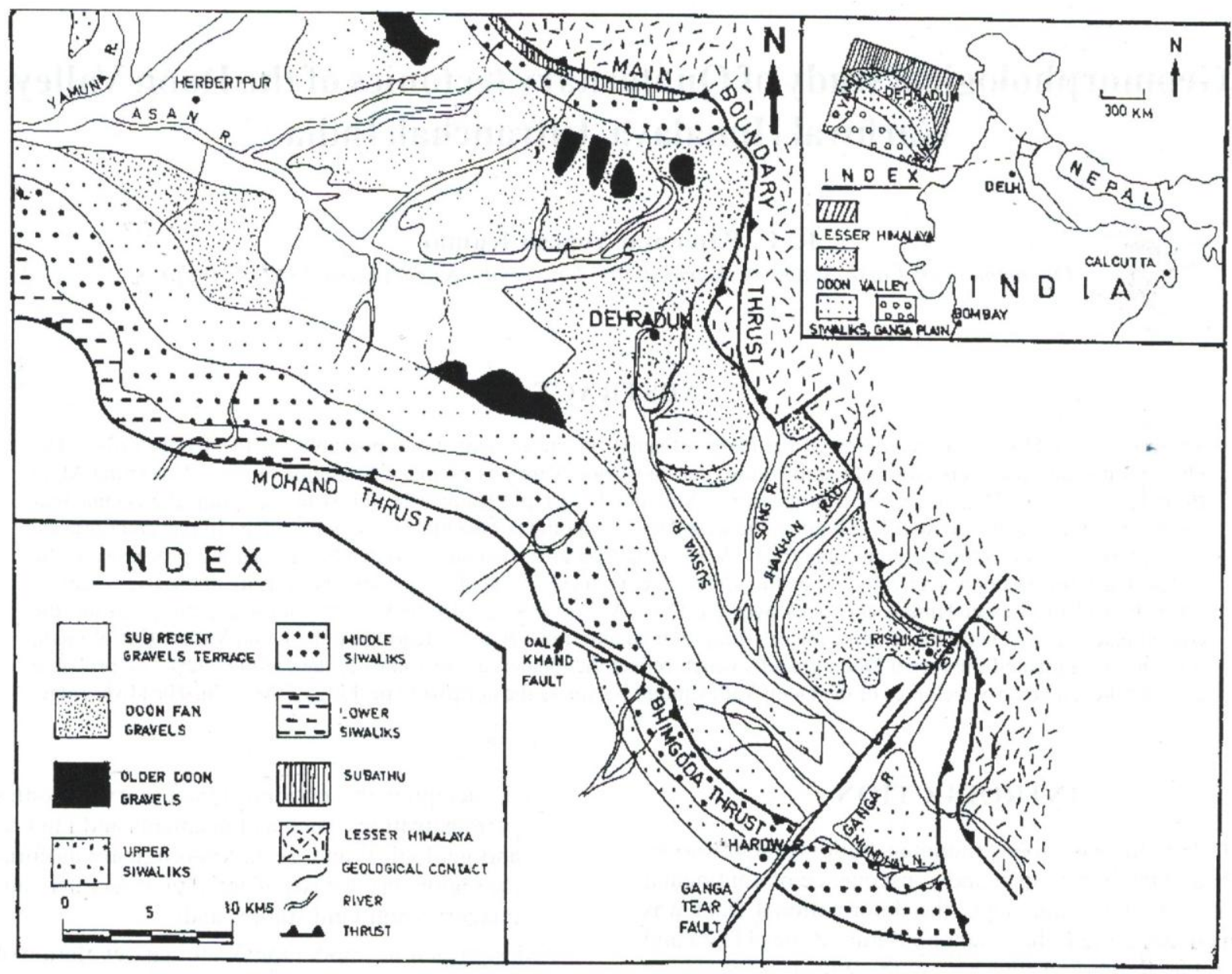

Fig. 1: General geological and tectonic map of the Doon valley between the Ganga and Yamuna rivers prepared from aerial photographs, satellite imagery and available geological data. Compiled after Nossin 1971; Meijerink 1974; Raiverman et al. 1984).

characters, different rock units such as sub-recent gravels and terraces, Doon Fan, Older Doon Gravels, Upper Siwaliks, Middle Siwaliks, Lower Siwaliks, Subathu and Pre-Tertiary rocks are identified (Fig. 1). All the boundaries of each unit have been approximately marked from aerial photographs, which matched strongly with the geological map of Meijerink (1974). The geology of the area studied is given in the Table 1.

Three broad E-W running parallel physiographic units are visible on the aerial photographs and satellite imageries. As one travels from south to north, the units encountered are (a) Doon intermontane valley, (b) Siwalik Hills and (c) Pre-Tertiary hills (Fig. 2).

The Doon valley is a flat-bottomed valley with thick cover of recently deposited alluvium (Fig. 2). The valley mainly comprises of oldest Doon gravels derived from the rising anticline of the Middle Siwalik rocks, Older Doon gravels derived from Upper Siwalik rocks and Pre-Tertiary rocks, and younger Doon gravels derived from the Pre-Tertiary rocks.
The Siwalik Hills consists of several parallel ranges occurring as barrier in the north and south sides of the Doon valley. These ranges are present in the south of the MBT and north of the Mohand and Bhimgoda Thrusts.

The Pre-Tertiary hills are elongated to the north of the MBT and in the east of Ganga Tear Fault. It has low relief with general slope towards south.

The major thrusts in the area are marked easily by means of aerial photographs and satellite imagery (Fig. 1 and 3). The MBT, which serves as the junction between the PreTertiary of the Lesser Himalaya and the Tertiary of the Siwaliks, forms the northern boundary of the valley. The concealed Mohand Thrust and Bhimgoda Thrust that extend along the outer edge of the Siwalik Hills represent the southern boundary of the valley. The Ganga Tear Fault demarcates the eastern boundary and the western margin is by the Yamuna Tear Fault (Not shown on the map). These faults are concealed but demarcated by the displacement of the Siwalik ranges along these faults. 
Geomorphological study of Quaternary tectonics of the Doon Valley, Garhwal Himalaya, Uttranchal

Table 1: Stratigraphy of the Doon valley and its adjacent area (After Aditya et al. 1976)

\begin{tabular}{|l|l|l|}
\hline \multicolumn{1}{|c|}{ Age } & \multicolumn{1}{|c|}{ Formation } & \multicolumn{1}{c|}{ Lithology } \\
\hline Quaternary & Doon Fan Gravels & $\begin{array}{l}\text { Gravel, Pebble, Boulder bed, Clay, Mixture of sandy, } \\
\text { Gravelly clay (Fan deposits, braided river deposits) }\end{array}$ \\
\hline Pliocene & Upper Siwaliks & Conglomerate, Clay \\
\hline Upper Miocene & Middle Siwaliks & Friable sandstone and claystone \\
\hline Middle Miocene & Lower Siwaliks & Sandstone, Claystone \\
\hline Lower Miocene & $\begin{array}{l}\text { Pre-Siwalik (Equivalent } \\
\text { to Dharamsala stage) }\end{array}$ & Shale, Clay, Siltstone \\
\hline Eocene & Subathu Formation & Siltstone, Shale, Sandstone \\
\hline \multicolumn{2}{|c|}{ Main Boundary Thrust } \\
\hline Mesozoic and Palaeozoic & Pre-Tertiary rocks & Slate, Phyllite, Quartzite, Meta-Limestone \\
\hline
\end{tabular}

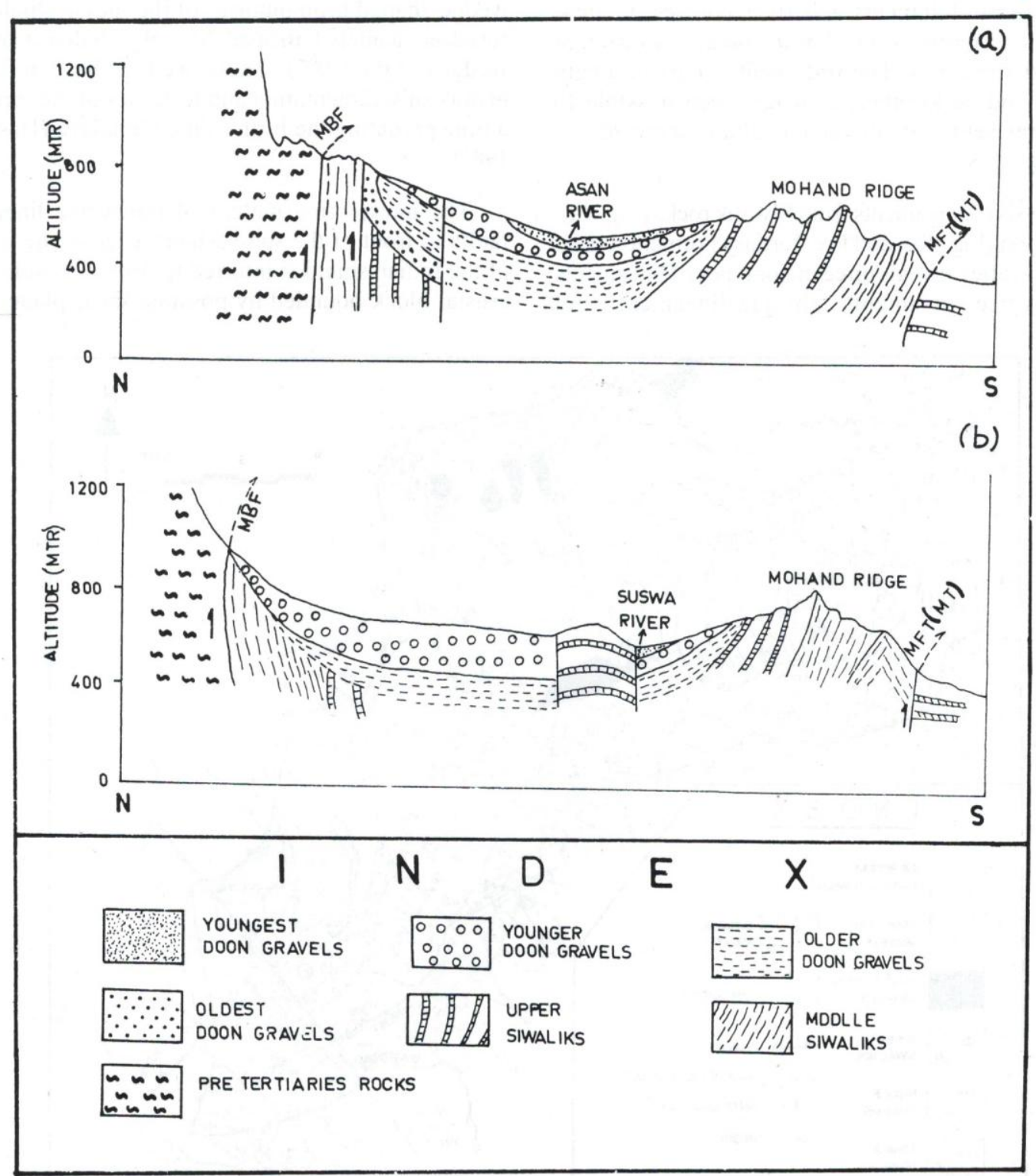

Fig. 2: Geological cross sections across (a) the Asan river in the west of Dehradun (b) the Suswa river in the east of Dehradun (After Meijerink 1974). 


\section{R. C. Patel and Yogesh Kumar}

Except these major faults and thrusts, some other important lineaments have also been mapped on the aerial photographs and satellite imagery (Fig. 3). These lineaments are trending mainly in two directions i.e. NW-SE and NESW.

In addition to faults, some axial traces of folds have been traced in the Siwalik range (Fig. 3). The Bhimgoda structure is the important one with a major thrust along the crest.

\section{LINEAMENT TECTONICS}

The aerial photographs and satellite images of the Doon valley reveal large number of lineaments (Fig. 3). Lineaments are identified based on rectilinear trends of morphological features, structural alignments and river courses, textural contrasts, tonal differences and linear contact of different lithologies and soil types. The lineaments range in length from few to hundred kilometers. It has been possible to decipher lateral sense of movement along some of the lineaments (Fig. 3).

Trend analysis of lineaments from Siwalik rocks (Fig. 4a), Recent Formation (Fig. 4b), and Pre-Tertiary Formation (Fig. $4 c)$ of the Doon valley reveals three major types of lineaments such as transverse lineaments, oblique lineaments and longitudinal lineaments. The transverse lineaments orient across the strike of the Himalaya whereas longitudinal lineaments trend parallel to the Himalayan orogen. The oblique lineaments orient between the transverse and longitudinal lineaments (Fig. 4). The transverse lineaments trending NE-SW are more prominently developed and are established fault as known from the ground mapping e.g. Ganga Tear Fault and Yamuna Tear Fault. In addition, several other transverse lineaments also produce noticeable offset on the MBT and MFT. Some of the lineaments are found cutting across the boundary of the Siwaliks and Doon gravels whereas other lineaments are confined in the Doon gravels. In the adjacent area of the Doon valley, similar types of lineament pattern are found (Fig. 4c). The transverse lineaments have generally followed the outline of three wedge-shaped promontories of the Indian shield below the foredeep, namely Faizabad, Monghyr-Saharsa and Goalpara wedges (Jain 1987). These wedges have influenced the history of sedimentation and tectonics of the foredeep since a time predating the birth of the Himalaya (Dasgupta et al. 1987).

The intersecting pattern of transverse lineaments and faults in front of the sub-surface sedge at the leading edge of the Indian shield is inferred to form a mosaic of rhombic crustal block bounded by possible shear planes (Dasgupta

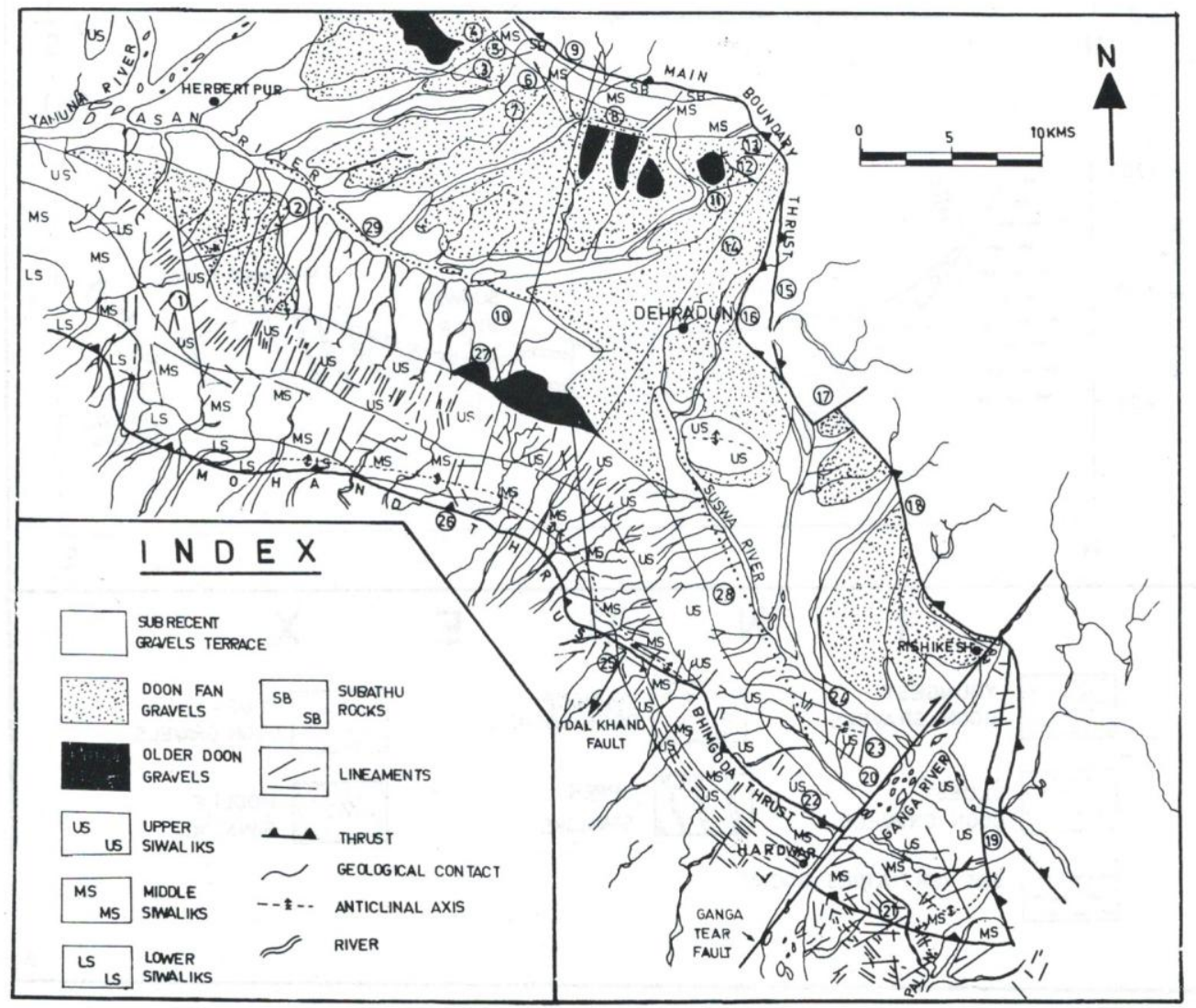

Fig. 3: Lineament-tectonic map of the Doon valley showing lineaments and structures (prepared from aerial photographs, satellite imagery). 


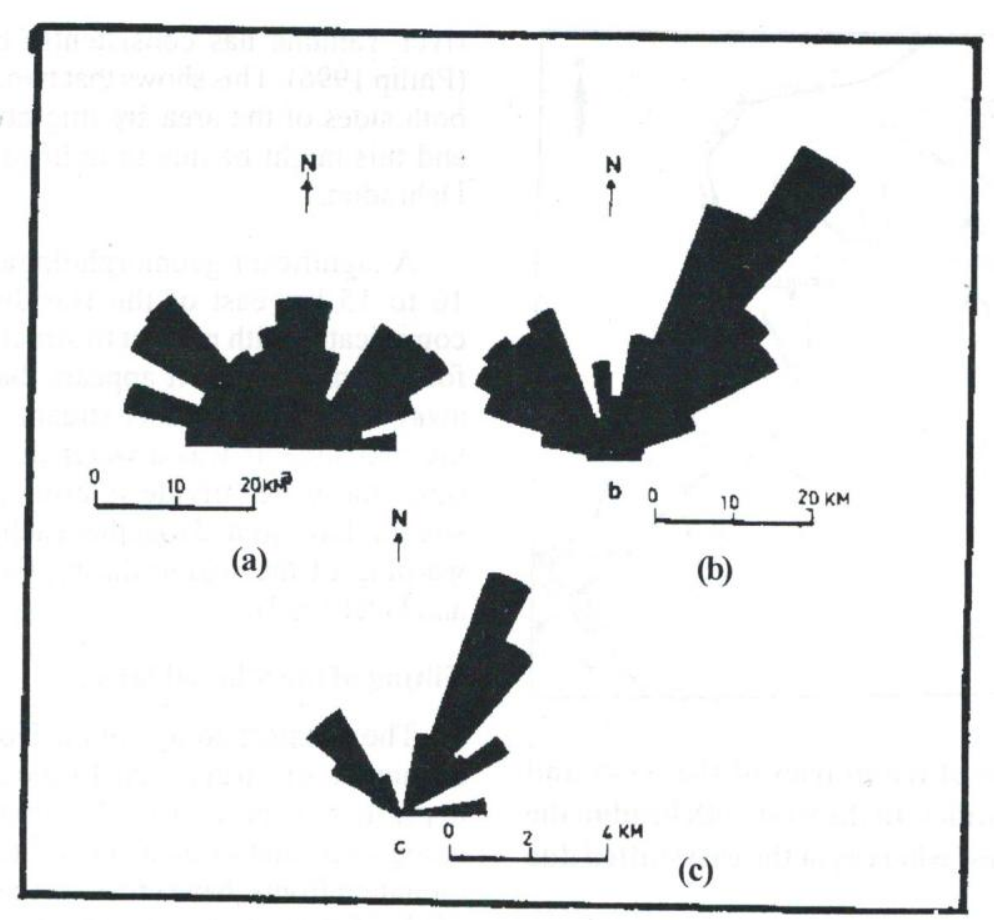

Fig. 4: Rose diagram of orientation of lineaments in (a) Doon gravels (b) Siwalik mountains and (c) Pre-Tertiary mountains adjacent to Doon valley. (Angle about the centre of the circle represents the compass azimuth and distance from the centre represents length of the lineaments).

et al. 1987). Jain (1987) identifies four sets of lineaments (L1, L2, L3, and L4) due to large-scale strike-slip movement in this region. Of these the $\mathrm{L} 1$ and $\mathrm{L} 3$ lineaments trending due $\mathrm{N}$ and $\mathrm{N} 35^{\circ}$ reveal dextral and sinistral strike-slip sense of movements whereas L2 and L4 lineaments trending N20 and $\mathrm{N} 95^{\circ}$ show dextral and sinistral sense of displacement respectively.

\section{GEOMORPHOLOGICAL EVIDENCES FOR QUATERNARY TECTONICS}

\section{Drainage re-orientation}

The surface and different rock units have developed a complex network of fluvial channels (Fig. 2). In pre-Tertiary Formation, the drainage pattern is dendritic and trellis whereas in the Siwalik Formation, the pattern is sub-parallel and dendritic. In recent formation, the drainage pattern is parallel and sinuous. The major rivers flowing in the region are Yamuna, Asan, Suswa, Song, Jhakan Rao and Ganga. The Yamuna river flows from north to south in the west whereas the Ganga river flows from NE to SW in the east.

The physiographic features control the courses of the rivers in the Doon valley. One typical feature of the Doon valley is that the Dehradun region represents a spur and acts as a waterdivide. In the east of the Dehradun region, the Suswa and Song rivers flow due east whereas in the west of Dehradun, the Asan river due west (Fig. 5). South of Dehradun, the Siwalik range serves as waterdivide for several small to intermediate rivers. The remarkable thing to note here is that on the northern slope from about the middle of the hill, the rivers on the western side flow northward and feed to the Asan river while on the eastern side the rivers flow north-east direction and feed to the Suswa river (Fig. 5). Hence, the middle of the east-west running Siwalik foothill serves as the water parting in the region. On the southern slope of the foothill similar pattern of rivers is also observed on the aerial photographs and satellite imagery. Hence, from the said middle point of the hill, if a line is drawn to little west of Dehradun, the position of the water parting becomes very distinct. By extending the line towards further south also the evidence of a subsurface water parting is found. South of the Siwalik hill in the alluvium, the rivers on the western side of the line flow towards the river Yamuna whereas the rivers on the eastern side flow towards the river Ganga. From above observation, it is clear that there exists a linear subsurface feature between the rivers Yamuna and Ganga extending from south towards further north joining the approximate middle part of the Siwalik foothills and the area little west of Dehradun. This linear feature may be interpreted as an extension of some Pre-Cambrian promontories from the peninsular shield in the south. The waterdivide around Dehradun is described due to uplift of the Dehradun region due to strike-slip movement and pushing of the DelhiHaridwar ridge (Karunakaran and Rao 1979).

Another typical feature of the channels of the Doon valley is more interesting. The tributaries on the north side of the Asan river flow from north to south whereas tributaries 


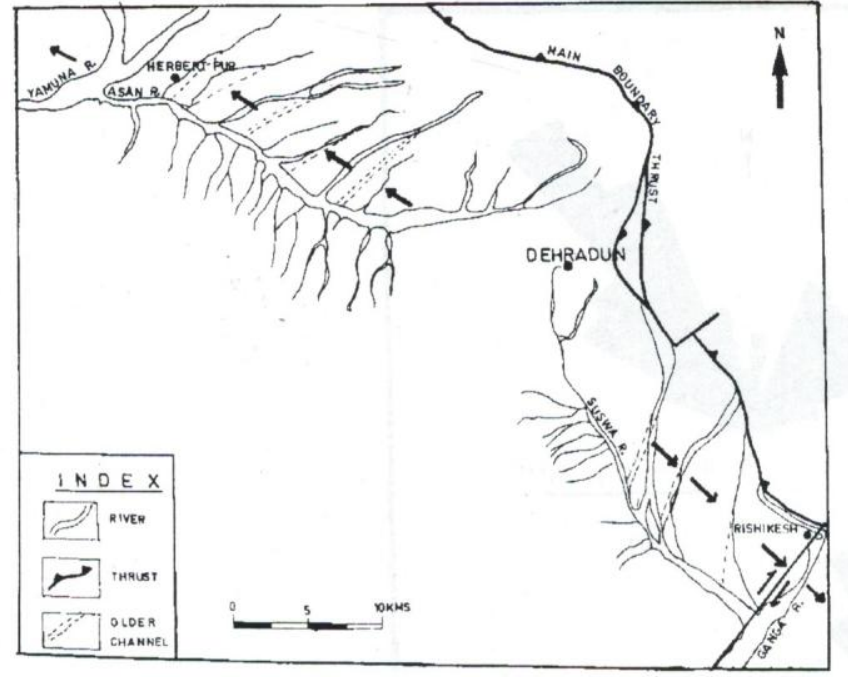

Fig. 5: Shifting in course of tributaries of the Asan and Suswa rivers in the Doon valley. In the west of Dehradun the rivers have shifted due west whereas in the east shifted due east.

in the south from south to north. The tributaries in the northern side join the river Asan at an angle of about 50 to 60 and form "horse tail like feature" (Fig. 3). Away from the river, the tributaries are still straight and normal to the trend of the Asan river. Philip (1996) has worked out from the imagery that the confluences of these tributaries with the Asan river was at a higher angle than the present day confluence angle indicating a gradual shifting of the river towards west in the recent past (Fig. 5). In the southern side of the Asan River, the tributaries flow straight and meet the Asan river at right angle. Similar types of geomorphotectonic features are also observed in the eastern side of the Dehradun region i.e. along Suswa river. The tributaries flowing from north meet the Suswa river at a different angle whereas the tributaries from southern side are still at right angle. It indicates that the Suswa, Song and Jhakan Rao and other tributaries are gradually shifting due east (Fig. 5).

Study of the aerial photographs shows that the Ganges flows along fault that displaces the Siwalik rocks. That fault is known as Ganga Tear Fault. The movement along Ganga Tear Fault has changed the stream course in western bank of the Ganga river and consequently, the rivers become convex southward. It implies that the Ganga Tear Fault is a dextral strike-slip fault of which the western block has moved towards north. In addition to it, the Ganges is gradually shifting its course towards east. Thick vegetation and growing townships now cover some of the areas where the Ganges was flowing once. The sinuous pattern of vegetation and the smooth and light black tone in non-vegetative region in the western bank represent the previous course of river. The changes in the course of the river were surely gradual as is evidenced from the overlapping sinuous marks of the main channels. On the other hand, it is observed that the river Yamuna has consistently been migrating westward (Philip 1996). This shows that two major rivers flowing along both sides of the area are migrating away from each other and this might be due to uplift of the Doon valley around Dehradun.

A significant geomorphological feature is noticed just 10 to $15 \mathrm{~km}$ east of the Haridwar (Fig. 6). The area is complicated with respect to structures. The area is intensely folded and faulted. It appears that one stream is capturing away the course of other stream. Earlier the central part of the two streams was a water divide. But in due course of time, the water divide is eroded and gradually the both streams have joined together each other. This result of down warping of the region during Quaternary tectonics (Joshi and Patel 1997).

\section{Tilting of the alluvial fans}

The geomorphology of the Doon valley is dominated by a number of large, well-formed alluvial fans which are deposited at the foot of the mountain blocks. It has been recognized that alluvial fans, the distinctive landforms of mountain fronts, have cross sectional profiles (from the head of the fan to its base), which are smoothly and broadly concave upward. The fans are approximately conical in shape under geometrically simple and tectonically stable conditions. Photogelogical observation of the alluvial fans present on the northern side of the Asan and Suswa rivers in the Doon valley are not in normal conical shape but those became segments of ellipses (Fig. 7). The elongation of the

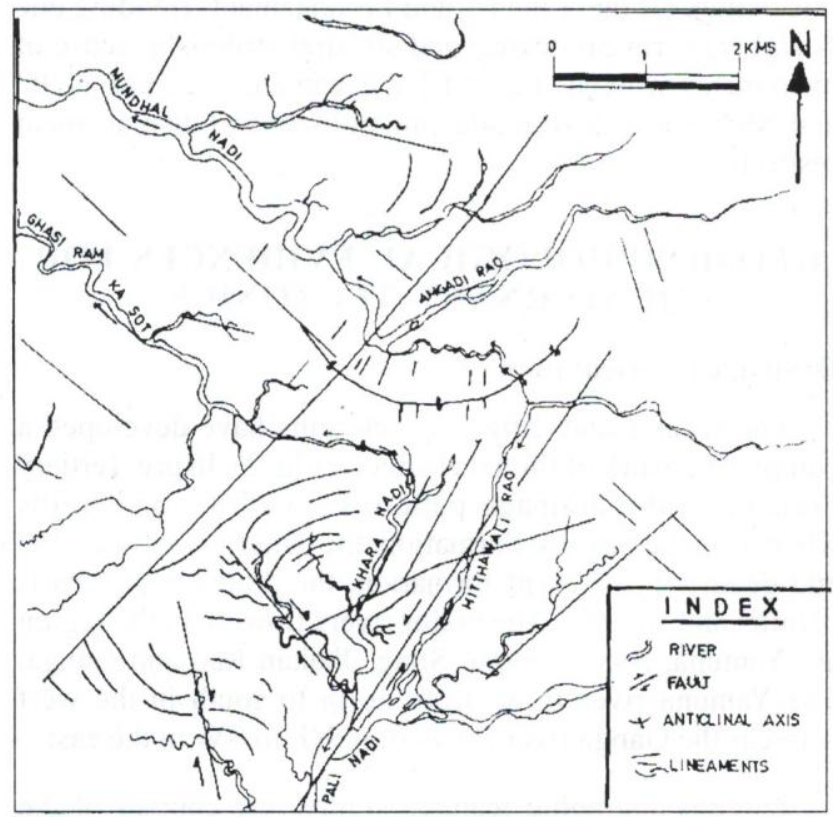

Fig. 6: Eating away the course of one stream by other stream (evidence of subsidence) and displacement of linear features along faults in the northeastern side of Haridwar in the Doon valley (prepared from the aerial photographs) (After Joshi and Patel 1997). 
conical alluvial fans into elliptical shape is sensitive only to horizontal component of rotation but not due to rotation about vertical axis pivot a fan. In the extreme case, rotation about a vertical axis will pivot a fan without altering its shape (Pinter and Keller 1995). But it is not the case in Doon valley. Considering this fact, the word tilt is used here to denote the purely horizontal component of rotation. Change in shape caused by tilting is most clearly preserved where the fan or segments of it have been rendered depositionally inactive. If the deposition on the fan had exceeded the tectonic deformation, it would have tended to anneal the fan and returned it to the conical shape (Pinter and Keller 1995). It is observed from the aerial photographs that the alluvial fans in the northern side of Asan and Suswa rivers are not in normal shape but are in elliptical shape. It implies that those fans depositional inactive. So it can be inferred that the alluvial fans in northern side of the Asan River are tilted due west whereas the alluvial fans in the northern side of the Suswa river are tilted due east (Fig. 6) (Joshi and Patel 1997), both with northward tilt component. Apart from this at places north of Asan and south of MBT, southern side of alluvial fans shows upliftment compared to the northern side, which can be attributed to recent tectonic phenomena. In the western Doon valley, there is gradual increase in the depth of the ground water table from west to east (Chandra et al. 1994). This change is possibly due to westerly tilt of the Doon fan (Philip 1996) and due to fast uplift of the Dehradun region relative to eastern and western side of the Doon valley.

\section{River terraces}

Three to four cycles of terraces are more distinct along the rivers Yamuna, Asan, Suswa, Song, Jhakan Rao and Ganges. The fluvial system has cut and preserved three uplifted terraces surfaces (T1, T2, T3) (Fig. 8). These terraces in the valley indicate major pulses of uplift in the Quaternary period. In conjunction with deep gorge and breaks in the river gradients, the displacement of terraces and faulting indicate neotectonic activities. It is also observed that there is no uniform height of same terraces along all the rivers. This indicates that uplift rate is unequal in the region. Part may be due to independent behavior of blocks on either side of wrench faults. On the northern side of the Doon valley on Tons River this kind of terrace displacement is observed along the MBT. Terraces development in the western flank of the Yamuna valley indicates consistent westward migration of the Yamuna river in the intermontane valley (Philip 1996).

\section{Evidence from the Main Boundary Thrust (MBT)}

The Main Boundary Thrust (MBT) separates the preTertiary Lesser Himalayan rocks from the Sub-Himalayan rocks and Doon valley. Study of the aerial photographs shows that the Lesser Himalayan rocks override the subrecent Doon gravels all the along the track between Dehradun and Rishikesh (Figs. 1 and 3). Other workers (Rajal et al. 1986) also have studied it. The Doon fan has been uplifted $290 \mathrm{~m}$

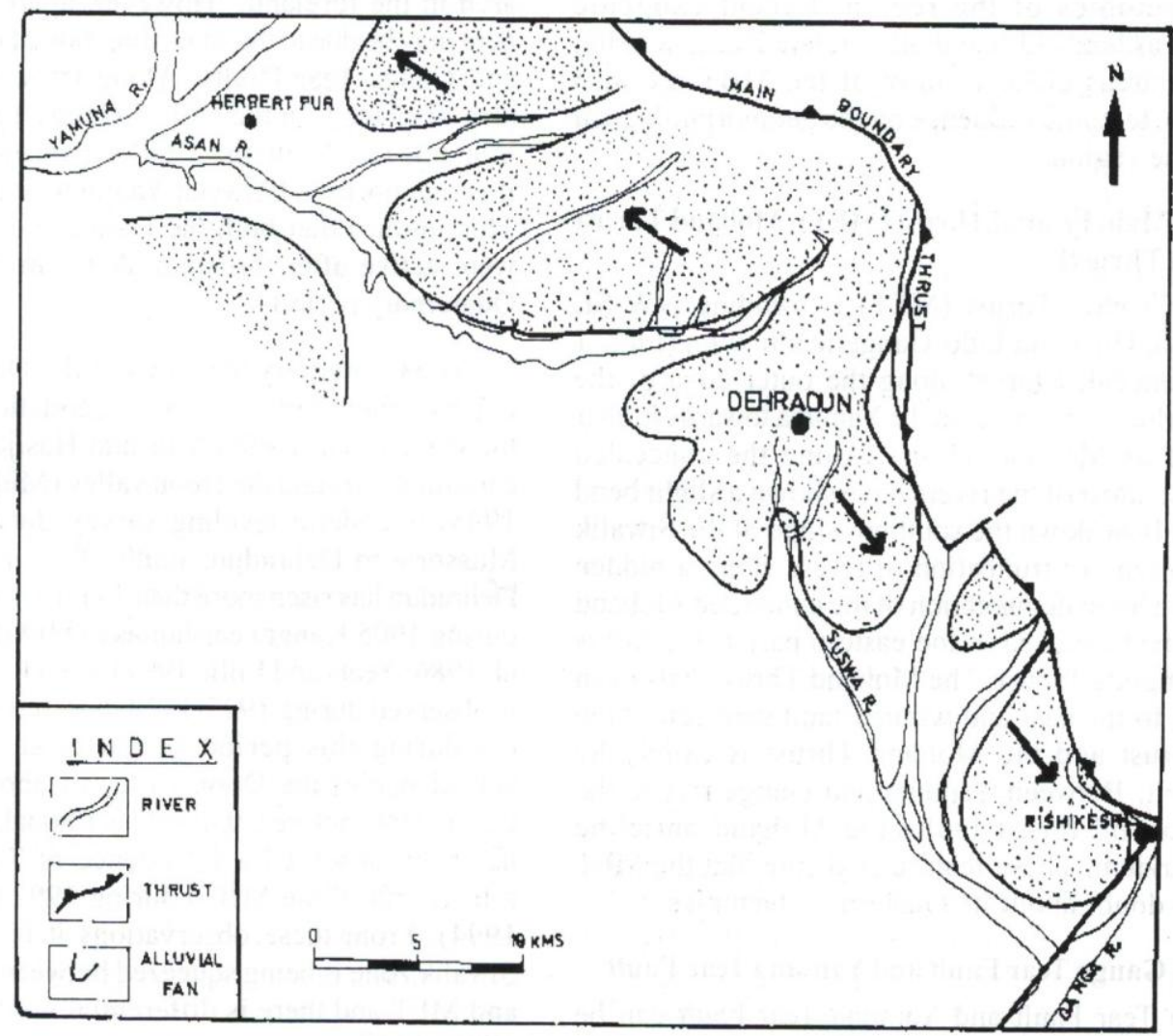

Fig. 7: Tilting of alluvial cones in the Doon valley. 


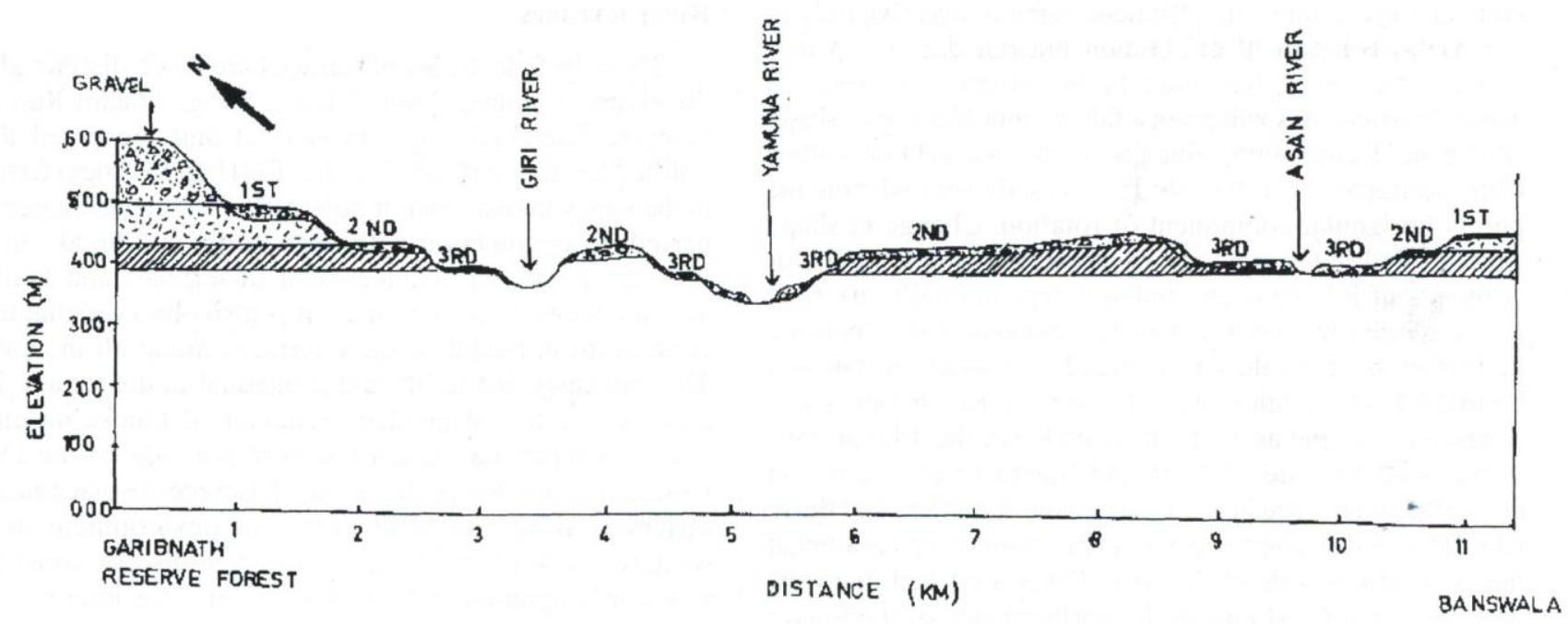

Fig. 8: Diagrammatic cross-section across terraces of the Yamuna-Asan rivers. Terrace elevations are from topographic maps. Gravel thickness is approximate.

on the slope of the Mussorie hill by movement along the MBT (Nossin 1971; Rajal et al. 1986). On the aerial photographs, a number of isolated outcrops of the Siwaliks are found within the Doon gravels. These appear to be faulted blocks, which have uplifted above the Doon gravels. The tectonics along the MBT is distinct evidences of Quaternary tectonics of the region. Recent exogenic processes such as landslides and other related mass wasting phenomena in areas close vicinity of the MBT are also testimony of the tectonic influence on the geomorphological processes of the region.

\section{Evidence from Main Frontal Thrust (MFT) (Mohand Thrust and Bhimgoda Thrust)}

The Main Frontal Thrust (MFT) is trending NW-SE between Siwalik Hills and Indo-Gangetic alluvium (Figs. 1 and 3). The concealed thrust along the outer edge of the Siwalik Hills, which extends from the Yamuna towards further east, is named as Mohand Thrust. Along the concealed Mohand Thrust, most of the rivers have shown a slight bend in their natural flow down the southern slope of the Siwalik foothills. Such type of truncation of rivers along a hidden line has helped a lot in demarcation of the concealed Mohand Thrust. The thrust exposed in the eastern part of the hill is called the Bhimgoda Thrust. The Mohand Thrust ends in an abrupt manner to the east and wrench fault connecting the Bhimgoda Thrust and the Mohand Thrust is called the Dholkhand fault. Between Yamuna and Ganga rivers, the concealed Mohand thrust faults the Mohand anticline against the alluvium. These features indicate that the MFT also leaves no doubt about its Quaternary tectonics.

\section{Evidence from Ganga Tear Fault and Yamuna Tear Fault}

The Ganga Tear Fault and Yamuna Tear Fault can be distinctly marked on the aerial photographs. The foothills between the Yamuna and Ganga rivers are offset to the north compared to their equivalent on either side. From the aerial photographs, it is observed that on the eastern side of the Ganga Tear Fault and western side of the Yamuna Tear Fault, the blocks have moved southwestward (Fig. 1). Talukdar and Sudhakar (1963) have described this due to Dharadun arch in the foreland. However, apart from this, the offset here may be due to the same direction of movement of Yamuna and Ganga Tear Faults. Along these faults, the MFT has also displaced. In the east of Ganga Tear Fault and west of Yamuna Tear Fault, the MFT is displaced due south whereas it is due north in between Yamuna and Ganga Tear Faults. This implies that both the Ganga and Yamuna Tear Faults were active after thrusting along the MFT i.e. during the Quaternary period.

The Quaternary tectonics of the Doon valley is worked out by other studies such as geodetic observation across the Ganga Tear Fault (Arur and Hasija 1986) and study of earthquake around the Doon valley (Middlemiss 1910; Wadia 1975). Geodetic leveling survey during 1904-1905 from Mussorie to Dehradun, south of the MBT has shown that Dehradun has risen more than $14 \mathrm{~cm}$ with respect to Mussorie during 1905 Kangra earthquake (Middlemiss 1910; Rajal et al. 1986; Yeats and Lillie 1991) and a further rise up to $4.7 \mathrm{~cm}$ is observed during 1927-1928 thus making a total uplift of 19 $\mathrm{cm}$ during this period (Rajal et al. 1986). However, a subsidence of the Doon valley of about $6 \mathrm{~cm}$ is observed during 1991 before Uttarkashi earthquake and Survey of India has been observed a subsidence of $7 \mathrm{~cm}$ of the Mussorie hills (north of the MBT) during 1992 (Rajal and Madhwal 1994). From these observations it is worked out that the Siwalik zone is being squeezed between the very active MBT and MFT and there is differential uplift in the Doon valley (Philip 1996). 


\section{TECTONIC MODEL FOR QUATERNARY UPLIFT OF THE DOON VALLEY}

The continental collision between the Indian and Eurasian plates along the Indus-Tsangpo Suture Zone (ITSZ) is followed by southward migration of the deformational front i.e. along the Zanskar Shear zone (ZSZ) (Patel et al. 1993), MCT and MBT. At present, the deformational front if confined at the foot of the Siwalik Hills and along the MFT (Mohand Thrust and Bhimgoda Thrust) (Nakata 1989). Consequently, uplifting, tilting of piedmonts and formation of uneven terraces and terrace upliftment and shifting of river courses, and active landslides along major thrusts are major Quaternary geomorphic expressions in the Doon valley. Geological, geophysical and aeromagnetic investigations carried out in the Indo-Gangetic plains have revealed that the peninsular rocks continue to extend as finger below the thick alluvium across the strike of the outer Himalayan hill ranges and one such subsurface features identified in the region is Delhi-Haridwar ridge (Sastri et al. 1971; Arora and Singh 1992). It is a linear NE-trending ridge, which has a very gentle slope towards NE. From this ridge the rectangular shaped Dehradun-re-entrant is extended between the Yamuna and the Ganga rivers (Karunakaran and Rao 1979; Raiverman et al. 1984). It strikes at right angles to the Siwalik range as well as the Lesser Himalaya and Higher Himalayan Crystalline (HHC). The maximum thickness of the Quaternary sediments near frontal Lesser Himalaya i.e. below the MBT is about $4 \mathrm{~km}$ (Raiverman et al. 1984). The thickness has reduced to less than $3 \mathrm{~km}$ on the western part and gradually becomes deeper to the SE of Mohand. Similarly, away from Poanta in the NW, the basin acquires some depth below Markanda (Kala Amb) area and gradually flattens out in Chandigarh region (Sati and Rautela 1998). The Mohand ridge is arched up in the middle and looks like an unsupported and a large hill between the rivers Yamuna and Ganga. It is convex due north with the point of inflexure in the centre. Along the Mussorie Ridge, the same inflexure is reflected. Thus, in the central sector of the Doon valley, the subsurface data show the presence of an elevated part of the basement, which is known as Dehradun re-entrant. It is also evident from the divergent drainage pattern. The Dehradun re-entrant is continuing pushing due NE (Talukdar and Sudhakar 1963).

On the basis of fracture trace and lineament analysis, significant southwestward strike-slip movements is some parts of the Siwalik belts are postulated on the flanks of the rectangular blocks (Jain 1987). The Middle and Upper Siwaliks between the Yamuna and Ganga Tear Faults are juxtaposed against the Lower Siwalik due to southwest movement along the flanks of these blocks. Due to interaction, SW-trending strike-slip movements seem to have resulted in two major faults along the Yamuna and Ganga rivers (Jain 1987). The Dehradun re-entrant is, therefore, playing an important role for Quaternary tectonics in the Doon valley.

It is suspected that a single fault was formed along the rivers Asan and Suswa during Himalayan tectonics. Sati and
Rautela (1998) have suggested it as thrust along which an anticlinal structure in the upper Siwaliks thrust over the Holocene gravels and boulders in the synclinal basin. However, the nature of drainage pattern indicates a strikeslip fault. Gradual strike-slip movement of the Dehradun reentrant due NE, stage-wise development has taken place during Quaternary period as discussed below (Fig. 9).

Due to northward strike-slip movement of the Dehradun re-entrant, the Dehradun region was uplifted and the fault along Asan-Suswa rivers was detached into two separate faults i.e. fault along Asan river and fault along Suswa river. The Asan river flowed along the fault due west whereas the Suswa river flowed along fault due east of Dehradun and the Dehradun was acted as water divide (Fig. 9). Due to further uplift of the Dehradun region, movements along both faults took place.

Before movement along both Asan and Suswa faults, the confluence of the tributaries in the north of the Doon valley with the Asan and Suswa rivers were at high angle then the present day confluence angle and the tributaries were flowing straight to both rivers, but probably there were no tributaries flowing from the south of Asan and Suswa rivers. The alluvial fans were formed and coalesce together to form normal conical piedmont at the foot of the Siwaliks on the northern side of the Doon valley. Tilting as well as strike-slip movement along both Asan and Suswa faults started due to further northeastward strike-slip movement of the Dehradun re-entrant and uplift of the Dehradun region. The blocks in the northern flank of the Asan and Suswa rivers relatively tilted and moved due west and east respectively. Consequently, the tributaries from north of the Doon valley gradually shifted their courses and turned westward and eastward respectively against the direction of the general gradient forming "horse tail like feature". The tributaries are more curved near the rivers whereas it is almost straight away from them. This implies that movement along Asan and Suswa faults is more effective near them whereas it is present less away from them. The conical and circular piedmonts, which had formed earlier, are tilted and became segment of ellipses. It implies that the horizontal component of rotation was more sensitive than rotation about vertical axis. Tilting due to horizontal rotation is clearly preserved as the piedmont or segments of it have been rendered depositionally inactive. It indicates that the neotectonic deformation is faster than the deposition on the fans.

The deformation along the Asan and Suswa faults was then shifted to south along the MFT. The Siwalik rocks were thrust over the Indo-Gangetic plain along the MFT and simultaneously the Mohand anticline structure evolved. The Mohand structure is since then have acted as waterdivide. The streams started flowing due north and south of the Mohand structure. The streams flowing due north joined the Asan and Suswa rivers at right angle and no significant shifting of their course have taken place till in recent times. The upliftment of the Mohand ridge and the tributaries from south of Asan and Suswa rivers are the result of neotectonic 


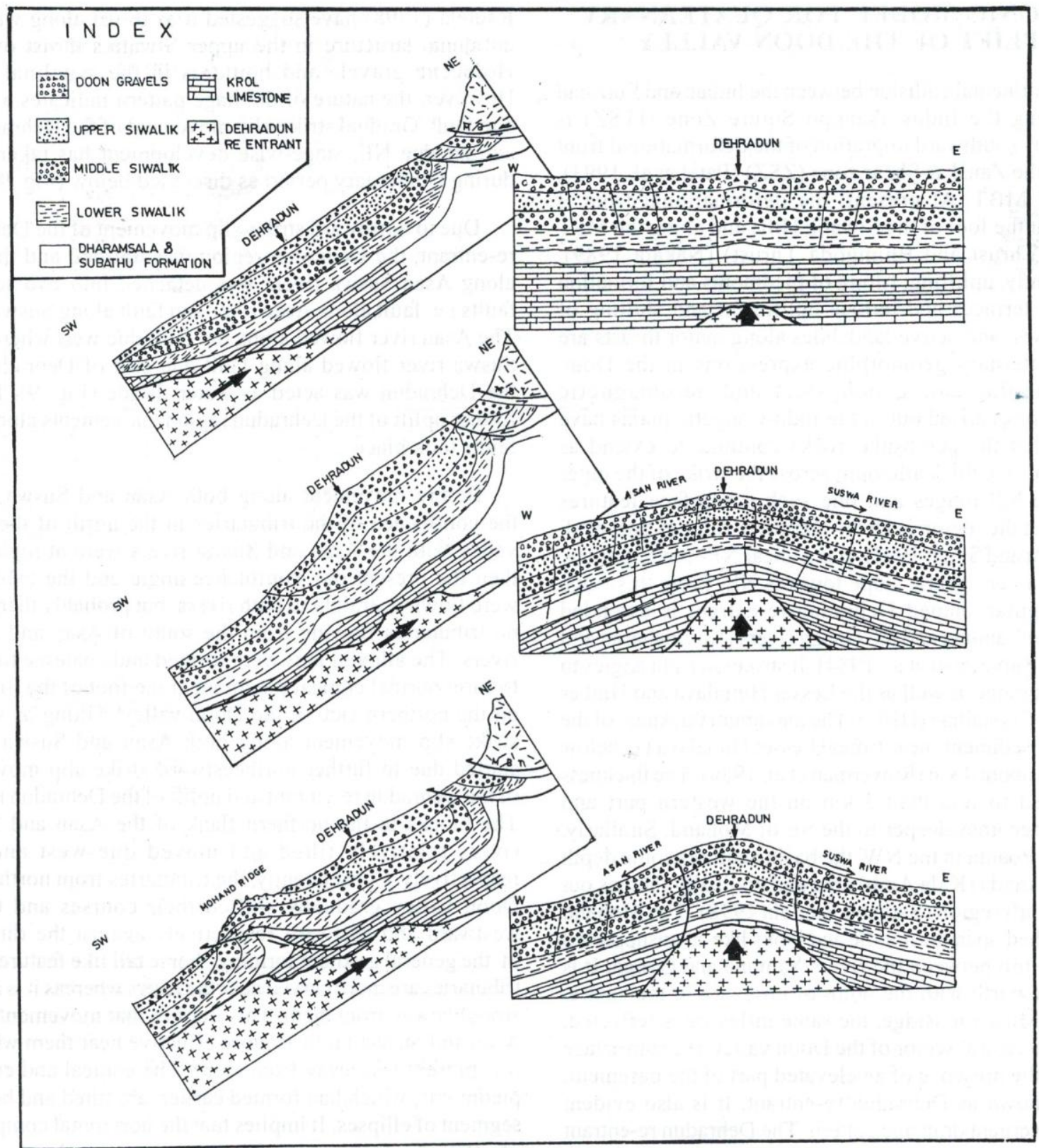

Fig. 9: Diagrammatic sketches illustrating development of the Doon valley during Quaternary period

(a) Deposition of the Doon gravels took place on the flat base Siwalik rocks

(b) Upliftment of Dehradun region started due to northeastward pushing of the Dehradun re-entrant and Asan river flowed towards west while Suswa river flowed towards east and

(c) Along with uplift of the Dehradun region, rise of the Mohand anticline took place with movement along the Main Frontal Thrust (MFT).

activity in the region. Northward movement of the Dehradun re-entrant below the Siwalik hill ranges and Doon valley has controlled the flow of the tributaries flowing from the Mohand ridge. On the northern slope from about middle part of the Siwalik hills, the streams in the western side have confluences with the Asan river while in the eastern side to the Suswa river. The gradual uplift of the Dehradun region due to pushing of Dehradun re-entrant has caused shifting of the Ganga and Yamuna rivers towards east and west respectively.

Geodetic survey of this region also shows growth of the Dehradun valley and Mohand anticline with respect to the MBT and Lesser Himalaya after the 1905 Kangra earthquake. After the earthquake the Mohand anticline continued to rise with respect to Dehradun valley and the Ganga plain (Rajal 
et al. 1986; Yeasts and Lillie 1991). It also shows that the upliftment of Mohand ridge is younger than the Dehradun valley and Ganga plain. The Doon valley is not only uplifting but also subsiding at some places as an effect of neotectonic activities in the region.

\section{CONCLUSIONS}

From the study of the geomorphological features of the Doon valley from the aerial photographs, it is interpreted that the Doon valley and its adjacent region are tectonically active. Neotectonics in the Doon valley is suggested due to continuous northward pushing of the Delhi-Haridwar ridge and due to active MBT. As a result of the neotectonic, upliftment of the Dehradun region and Mohand ridge, tilting of the piedmonts, changing of river courses, upliftment of the river terraces and subsidence of landmass at some places has taken place. Many of the neotectonic lineaments are worked out as faults and structural dislocation zones. The study shows that such neotectonic lineaments have the imprint of evolution of the Dehradun valley in the geological past.

Neotectonic activities have caused many geomorphological changes in the whole region and have greatly affected the subtle and loose alluvial depositional set-up of the Doon valley and sedimentary deposits of the Siwaliks. Due to movement and pushing of the DelhiHaridwar ridge below the Dehradun region, the area is undergoing intense strain build up, the future large-scale earthquake might cause catastrophic modifications of the Doon valley and the existing lineaments may get reactivated causing further movement of the rock masses in the basin. Seismic zonation map for moderate as well as great earthquake indicates the areas around Dehradun, Rishikesh and Haridwar are highly exposed to the seismic hazard and can experience accelerations around $300 \mathrm{~cm} / \mathrm{s}^{2}$ to $600 \mathrm{~cm} / \mathrm{s}^{2}$ due to future earthquakes in the region. This study also shows that faults, which are represented by longer lineaments, are more significant for earthquake resistant design parameters in this region than those faults, which are represented by smaller lineaments (Joshi and Patel 1997).

\section{ACKNOWLEDGEMENTS}

The authors are grateful to Dr. P. K., Champti Roy, Scientist, HRS, Dehradun, Prof. Nand Lal, Department of Earth Sciences, K.U., Kurukshetra, for constant encouragement and unending enthusiasm.

\section{REFERENCES}

Arora, B. R. and Singh, B. P., 1992, Geomagnetic and geoelectric investigations for seismicity and seismotectonics of the Himalayan region. In: Gupta, G. D. (ed.), Himalayan Siesmology, Mem. Geol. Soc. India, v. 23, pp. 223-263.

Arur, M. G. and Hasja, N. L., 1986, Crustal movement studies across Ganga Tear Fault (in Siwaliks) at haridwar in Uttar Pradesh India. Int. Sym. On Neotect. South Asia, Surv. India, Dehradun, pp. 353-365.
Chandra, U., 1978, Seismicity, earthquake mechanism and tectonics along the Himalayan Mountain Range and vicinity. Phy. Earthqu. Planet. Inter., v. 16, pp. 109-131.

Chandra, R., Paul, S., and Jugran, D. K., 1994, Hydromorphological mapping of western part of Doon Valley using remote sensing and GIS technique. In: Murali Krishna, I.V. (ed.), Proc. ICORG-94 on Remote Sensing and GIS for Environmental Planning, Hydrabad, (Supplementary volume), Tata McGrawHill Publishing Co. Ltd., New Delhi, pp. 36-45.

Dasgupta, S., Mukhopadhyay, M., and Nady, D. R., 1987, Active transverse fractures in the central portion of the Himalaya. Tectonophysics, v. 136, pp. 255-264.

Jain, A. K., 1987, Kinematics of the transverse lineaments, regional tectonics and Holocene stress field in the Garhwal Himalaya. Geol. Soc. India, v. 30(3), pp. 169-186.

Joshi, A. and Patel, R. C., 1997, Modelling of active lineaments for predicting a possible earthquake scenario around Dehradun, Garhwal Himalaya, India. Tectonophysics, v. 283, pp. 289-310.

Karunakaran, C., and Ranga Rao, A., 1979, Status of exploration for hydrocarbons in the Himalayan region: contributions to stratigraphy and structure. In: Himalayan Geology Seminar1976. Geol. Surv. India Misc. Pub. v. 41, pp. 1-66.

Khattri, K. N. Rai, K., Jain, A. K., Sinvhal, H., Gaur, V. K., and Mithal, R. S., 1971, The Kinnaur Earthquake, Himachal Pradesh, India of 19 January, 1975. Tectonophysics, v. 49, pp. 1-21.

Khattri, K. N. and Tyagi, A. K., 1983, The transverse tectonic features in the Himalaya. Tectonophysics, v. 90, pp. 19-29.

Meijerink, A. M. J., 1974, Photohydrological Reconnaissance Surveys. Specl. Pub. I.T.C., Enscheda,

Middlemiss, C. S., 1910, The Kangra earthquake of $4^{\text {th }}$ April, 1905. Mem. Geol. Surv., India, 38 p.

Molnar, P. and Tapponnier, P., 1975, Cenozoic tectonics of Asia: effect of a continental collision. Science. v. 189, pp. 419-426.

Nakata, T., 1972, Geomorphic history and crustal movement of the foothills of the Himalaya. Tohoku University, Institute of Geography, pp. 39-77.

Nakata, T., 1989, Active faults of the Himalaya of India and Nepal. Spec. Pap., Geol. Soc. Am., v. 232, pp. 243-264.

Ni., J. and Barazangi, M., 1984, Seismotectonics of the Himalayan collision zone: geometry of the underthrusting Indian plate beneath the Himalaya. J. Geophys. Res., v. 89, pp. 1147-1163.

Norton, I. O. and Sclater, I. G., 1979, A model for the evolution of the Indian Ocean and break up of the Gondawana land. Jour. Geophys. Res., v. 84, pp. 6803-6830.

Nossin, J. J., 1971, Outline of the geomorphology of the Doon valley, northern U. P., India. Z. Geomorph., v. 12, pp. 18-50.

Patel, R. C., Singh, S., Asokan, A., Manickavasagam, R. M., and Jain, A. K., 1993, Extensional tectonics in the Himalayan orogen, Zanskar, NW India. In: Himalayan Tectonics (Treloar, P. J. and Searle, M. P. eds.), Geol. Soc., Spec. Publ. No. 74, pp. 445-459.

Patriat, P. and Acache, J., 1984, India-Eurasia collision chronology has implications for crustal shortening and driving mechanisms for plates. Nature, v. 311, pp. 615-621.

Philip, G., 1996, Landsat thematic mapper data analysis for Quaternary tectonics in parts of the Doon valley, NW Himalaya, India. Int. J. Remote Sensing, v. 17(1), pp. 143-153.

Pinter, N. and Keller, E. A., 1995, Geomorphological analysis of neotectonic deformation, northern Owen Valley, California. Geol. Rundsch., v. 84, pp. 200-212. 


\section{R. C. Patel and Yogesh Kumar}

Powell, C. McA., 1979, A speculative tectonic history of Pakistan and surrounding: some constraints from the Indian Ocean. In: Geodynamics of Pakistan edt. By A Farah and K. A., Dejong, Geol. Surv., Pakistan, Quetta, Pakistan, pp. 5-24.

Raiverman, V., Kunte, S. V., and Mukherjee, A., 1984, Basin geometry, Cenozoic sedimentation and hydrocarbon prospects in North western Himalaya and Indo-Gangetic plains. Petrol. Asia J., v. 6, pp. 67-92.

Rajal, B. S. and Madhwal, H. B., 1994, Geodetic studies of crustal deformation and fault displacements. In: Group Discussion on Geological Hazards in the Himalayan Region: Assessment and Mitigation, Wadis Institute of Himalayan Geology, Dehradun, pp. 36-37 (abstract)

Rajal, B. S., Virdi, N. S., and Hasija, N. L., 1986, Recent crustal uplift in the Doon valley. Proc. Int. Symp. Neotectonic in South Asia, Dehradun, India, pp. 146-159.

Rastogi, B. K., 1976, Source mechanism studies of earthquake and contemporary tectonics in Himalaya and nearby regions. Bull. Inter. Inst. Seismo. Earth Eng., v. 14, pp. 99-134.

Sastri, V. V., Bhandri, L. L., Raju, A. T. R., and Datta, A. K., 1971, Tectonic framework and subsurface stratigraphy of the Ganga Basin. J. Geol. Soc. India, v. 12, pp. 222-233.
Sati, D. and Rautela, P., 1998, Neotectonic deformation in the Himalayan foreland fold-and-thrust belt exposed between the rivers Ganga and Yamuna. J. Him. Geol., v. 19(10), pp. 21-27.

Talukdar, A. N. and Sudhakar, R., 1963, Structure of the southern edge of the Himalaya of North India. Geol. Surv. India, Misc. Publ. No. 15, (1972), pp. 185-194.

Valdiya, K. S., 1980, The two intracrustal boundary thrusts of the Himalaya. Tectonophysics, v. 66, pp. 323-348.

Valdiya, K. S., 1989, Trans-Himadri intracontinental fault and basement upwarps south of Indus-Tsangpo Suture zone. Geol. Soc. Am., Spec. Pap., v. 232, pp. 153-168.

Wadia, D. N., 1975, Geology of India. $4^{\text {th }}$ Edition, Tata McGrawHill Publishing.

Yeats, R. S., Khan, S. H., and Akhtar, M., 1984, Late Quaternary deformation of the Salt Range of Pakistan. Bull. Geol. Soc., Am., v. 95, pp. 958-966.

Yeats, R. S., and Lillie, R. J., 1991, Contemporary tectonics of the Himalayan frontal fault system, folds, blind thrust and 1905 Kangra earthquake. J. Struct. Geol., v. 13, pp. 215-225. 